\title{
PREVALENCE OF SELF-REPORTED SPINAL PAIN IN BRAZIL: RESULTS OF THE NATIONAL HEALTH RESEARCH
}

\author{
PREVALENNCIA DE DOR AUTORREFERIDA NA COLUNA VERTEBRAL NO BRASIL: \\ RESULTADOS DA PESQUISA NACIONAL DA SAÚDE
}

\section{PREVALENCIA DE LA AUTO-PERCEPCIÓN DEL DOLOR EN LA COLUMNA VERTEBRAL EN BRASIL: RESULTADOS DE LA INVESTIGACIÓN NACIONAL DE SALUD}

Luiza Gomes Santos ${ }^{1}$, Kristian Madeira' ${ }^{1}$, Willians Cassiano Longen ${ }^{1,2}$

1. Universidade do Extremo Sul Catarinense, Academic Department in Health Sciences, PhysicalTherapy Course of Study, Criciúma, SC, Brazil. 2. Universidade do Extremo Sul Catarinense, Post-Graduate Program in Collective Health (PPGSCol), Criciúma, SC, Brazil.

\begin{abstract}
Objective: To identify the prevalence and distribution of cases of self-reported spinal disorders by persons who are 18 years or older living in Brazil according to sociodemographic variables. Methods: We used the Pesquisa Nacional de Saúde (PNS, national health research), developed by the Brazilian Institute of Geography and Statistics (IBGE) in partnership with the Ministry of Health. The data obtained from the website of IBGE System of Automatic Recovery - SIDRA were analyzed using the SPSS Statistics software version 20.0, IBM. Results: In Brazil 19\% of the adult population report chronic spinal pain, $15.26 \%( \pm 4.56)$ men and $20.08 \%(+/-4.11)$ women. After the age of 60 , the prevalence is higher. Regarding skin color $18.26 \%( \pm 3.53)$ are white, $17.27 \%( \pm 6.65)$ are black and $17.93 \%( \pm 4.05)$ are brown, with no statistical difference. As for education, $23.55 \%( \pm 5.70)$ had low or absent schooling $(p<0.001)$. The southern region of Brazil has the highest percentage (23.3\%) of adults with chronic problems in the spine, and the state with the highest percentage is Paraná, with $26 \%$. Conclusions: The results showed that there is a relationship between spinal pain and sociodemographic characteristics, pointing to the southern region as the most affected by spinal disorders when compared to other regions of the country.
\end{abstract}

Keywords: Spine; Chronic pain; Epidemiology; Population surveys; Population.

\section{RESUMO}

Objetivo: Identificar a prevalência e a distribuição de casos de distúrbios da coluna vertebral autorreferidos por pessoas com 18 anos de idade ou mais, residentes no Brasil de acordo com variáveis sociodemográficas. Métodos: Utilizou-se a Pesquisa Nacional de Saúde (PNS), desenvolvida pelo Instituto Brasileiro de Geografia e Estatística (IBGE) em parceria com o Ministério da Saúde. Os dados obtidos no site do Sistema IBGE de Recuperação Automática - SIDRA foram analisados com o software SPSS Statistics versão 20.0 da IBM. Resultados: No Brasil, $19 \%$ da população adulta relatam dor crônica na coluna vertebral, sendo 15,26\% ( $\pm 4,56)$ homens e $20,08 \%( \pm 4,11)$ mulheres. Após os 60 anos de idade, a prevalência é maior. Com relação à cor da pele 18,26\% ( \pm 3,53) são brancos, 17,27\% ( \pm 6,65) são negros e $17,93 \%( \pm 4,05)$ são pardos, sem diferença estatística. Quanto à escolaridade $23,55 \%( \pm 5,70)$ não tinham nenhum nível de instrução ou tinham ensino fundamental incompleto $(p<0,001)$. A região sul do Brasil é a que apresenta o maior percentual $(23,3 \%)$ de adultos com problema crônico na coluna, e o estado com maior percentual é o Paraná, com 26\%. Conclusões: Os resultados mostraram que há uma relação entre dor na coluna e características sociodemográficas, apontando a região sul como a mais afetada pelos distúrbios da coluna vertebral, em comparação com as outras regiões do país.

Descritores: Coluna vertebral; Dor crônica; Epidemiologia; Inquéritos demográficos; População.

\section{RESUMEN}

Objetivo: Identificar la prevalencia y distribución de los casos de trastornos auto-reportados de la columna vertebral por personas con 18 años de edad o mayores, que viven en Brasil según variables sociodemográficas. Métodos: Se utilizó la Pesquisa Nacional da Saúde (PNS, investigación nacional de salud), desarrollada por el Instituto Brasileño de Geografía y Estadística (IBGE) en colaboración con el Ministerio de Salud. Los dados en el sitio web del Sistema IBGE de Recuperación Automática - SIDRA se analizaron con el software SPSS Statistics versión 20.0 de IBM. Resultados: En Brasil 19\% de los adultos reporta dolor crónico en la columna vertebral, 15,26\% ( \pm 4,56) hombres y $20,08 \%( \pm 4,11)$ mujeres. Después de los 60 años, la prevalencia es más alta. Con respecto al color de la piel 18,26\% ( $\pm 3,53)$ son de color blanco, $17,27 \%( \pm 6,65)$ son de color negro y 17,93\% $( \pm 4,05)$ son de color marrón, sin diferencia estadística. En cuanto a la educación $23,55 \%( \pm 5,70)$ no tenían ningún nivel de educación o tenían educación primaria incompleta $(p<0,001)$. El sur de Brasil es el que tiene el porcentaje más alto $(23,3 \%)$ de adultos con problema crónico de la columna, y el estado con el porcentaje más alto es el Paraná con 26\%. Conclusiones: Los resultados mostraron que existe una relación entre el dolor de la columna y las características sociodemográficas, señalando la región sur como la más afectada por trastornos de la columna vertebral, en comparación con otras regiones del país.

Descriptores: Columna vertebral; Dolor crónico; Epidemiología; Encuestas demográficas; Población. 


\section{INTRODUCTION}

Low back pain is one of the four most common diseases and it is a major economic problem in many countries. ${ }^{1-4}$ Its etiology, in most cases (up to $85 \%$ ), is unknown or nonspecific. ${ }^{1}$ Studies indicate that approximately $80 \%$ of the population will have one or more episodes of low back pain at some time during their life, being one of the most frequently encountered conditions in clinical practice.,

In the United Kingdom, low back pain is the most common cause of disability in young adults, being responsible for sending around 8\% of the adults of that country to consult a doctor for back pain each year. ${ }^{6}$ In Germany, a study conducted among workers to investigate lumbalgia in this population found that $34 \%$ of the workers had back pain during seven days and $60 \%$ of them had back pain for a year. ${ }^{7}$ In the United States, more than one quarter of the adults reported that they had been recently affected (within the last 3 months) by lumbalgia. In this same study, it was shown that the costs of treating low back pain, in the year 1998 alone, was approximately 90 billion dollars. ${ }^{5}$ In Brazil, a study conducted with workers insured by the social security system showed that the number of work days lost to disability retirements resulting from back pain was greater than 12 million, with idiopathic pain being the principal reason for these departures. ${ }^{8}$

Low back pain is an ever-present complaint with a higher prevalence among people during working years (67\%). ${ }^{9}$ Although it is often cited as an occupational consequence, a study conducted in the Czech Republic with specialists in occupational diseases in European countries reports that in some of the countries studied low back pain is still not recognized as an occupational disease unless the pain is caused by an injury resulting from performing professional activities. ${ }^{10}$ While low back pain is still not considered an occupational disease in some countries, the association between low back pain and work activity was clear in most of the studies we analyzed.

In 2013, in order to establish epidemiological data about spinal disorders, National Health Research (PNS - 2013) conducted a first-of-its-kind study in Brazil developed by the Brazilian Institute of Geography and Statistics (IBGE) in partnership with the Ministry of Health and with the Oswaldo Cruz Foundation (Fiocruz). The objective of PNS was to produce demographic data to describe aspects related to the health conditions of the Brazilian population, in addition to addressing the individual perception of health in various dimensions in order to define differences in morbidity in population subgroups, to compare the need for health services and resources by geographic area, as well as to calculate other indicators of morbidity-mortality, such as healthy life expectancy, and to elaborate public health care policies for access to health services, preventive actions, continuity of care, and health care financing. ${ }^{11-14}$

The objective of this study was to describe the prevalence of chronic spine problems self-reported by people 18 years of age or older living in Brazil according to sociodemographic variables.

\section{METHODS}

The statistical data used in this study were produced by National Health Research - 2013 and accessed via the IBGE Automatic Recovery System (SIDRA). The population studied comprised residents of private households in Brazil, with the exception of those located in special census tracts (barracks, military bases, temporary lodging, camps, boats, penitentiaries, penal colonies, prisons, residential care homes, orphanages, convents, and hospitals). The PNS sample is a sub-sample of the IBGE Master Sample of the Integrated System of Household Surveys (SIPD), the geographic coverage of which is formed by the census sectors of the Geographic Operational Base of the 2010 Demographic Census, with the exception of many small or special sectors. The Master Sample is a set of area units that are selected to serve various SIPD surveys. The PNS sample was selected in three stages, in which the census sectors or set of sectors formed the Primary Sample Units (UPAs). The households were the second stage units and residents 18 years of age or older defined the units of the third stage. The PNS questionnaire is subdivided into three parts: the household, all residents of the household, and the individual. The household and all residents of the household questionnaires were answered by one resident of the household able to report on the characteristics of the household, the socioeconomic situation, and the health of the residents. The individual questionnaire was answered by one resident 18 years of age or older selected by the data collection team with equiprobability among the other adult residents of the household. A total of 81,767 households were selected by PNS to participate. Following data collection, interviews were conducted in 62,986 households, this being the total number of individuals interviewed for the research, considering that PNS is based on the third stage, which involves the individual questionnaire. The interviews were conducted during the period from August 2013 to February 2014 and the data were collected using handheld computers (Personal Digital Assistance - PDA) programmed for this function. ${ }^{11-15}$

The data obtained from the IBGE site were statistically analyzed using IBM SPSS Statistics version 20.0 software. The results were expressed as averages, standard deviations, and frequencies. The inferential analyses were performed with a confidence level of 95\%. The normality of variable distribution was evaluated by means of the Shapiro-Wilk and Kolmogorov-Smirnov tests. The homogeneity of the variances was evaluated using the Levene test. The comparison of the averages obtained for the categories of the polyatomic variables was performed using ANOVA one-way variance, followed by the post hoc Tukey test when there was statistical significance. The comparison of the averages obtained for the dichotomic variables was performed using the Student's $t$-test.

\section{RESULTS}

As we can see in Table 1, in Brazil 19\% of the population aged 18 years and over report chronic spine pain. Of this number, $15.26 \%$ $( \pm 4.56)$ are men and $20.08( \pm 4.11)$ are women, with a significant difference between the sexes $(p<0.001)$. In relation to the age groups, the most affected individuals were adults belonging to the 60 to 64 years $(27.16 \% \pm 6.14), 65$ to 74 years $(26.67 \% \pm 8.13)$, and 75 years and above $(26.52 \% \pm 8.88)$ age groups, with no significant difference among these three age groups, followed by the 30 to 59 years $(19.86 \%+/-3.59)$ and the 18 to 29 years $(9.4 \% \pm 3.51)$ age groups, which points to the notion that chronic spine problems increase with age. As regards race, 18.26\% ( \pm 3.53$)$ were White, $17.27 \%$ $( \pm 6.65)$ Black, and $17.93 \%$ ( \pm 4.05$)$ Mixed race, without any statistical

Table 1. Percentage of individuals 18 years of age or older who report chronic spine problems in Brazil.

\begin{tabular}{|c|c|c|}
\hline Variable & Average \pm SD & p-value \\
\hline Sex & & \\
\hline Male & $15.26 \pm 4.56$ & \multirow{2}{*}{$<0.001$} \\
\hline Female & $20.08 \pm 4.11$ & \\
\hline \multicolumn{3}{|l|}{ Age Group } \\
\hline 18 to 29 years & $9.24 \pm 3.51^{\mathrm{a}}$ & \multirow{5}{*}{$<0.001$} \\
\hline 30 to 59 years & $19.86 \pm 3.59^{b}$ & \\
\hline 60 to 64 years & $27.16 \pm 6.14^{b}$ & \\
\hline 65 to 74 years & $26.67 \pm 8.13^{b}$ & \\
\hline$\geq 75$ years & $26.52 \pm 8.88^{c}$ & \\
\hline \multicolumn{3}{|l|}{ Color or Race } \\
\hline White & $18.26 \pm 3.53$ & \multirow{3}{*}{$<0.756$} \\
\hline Black & $17.27 \pm 6.65$ & \\
\hline Mixed race & $17.93 \pm 4.05$ & \\
\hline \multicolumn{3}{|l|}{ Education } \\
\hline SIFI & $23.55 \pm 5.70^{\mathrm{a}}$ & \multirow{4}{*}{$<0.001$} \\
\hline FCMI & $14.95 \pm 4.46^{b}$ & \\
\hline MCSI & $13.30 \pm 2.37^{b}$ & \\
\hline SC & $14.66 \pm 4.08^{b}$ & \\
\hline
\end{tabular}

$\mathrm{SIFI}=$ No schooling and incomplete elementary $-\mathrm{FCMI}=$ Complete elementary and incomplete secondary $-\mathrm{MCSI}=$ Complete secondary and incomplete college degree $-\mathrm{SC}=$ College degree ${ }^{\mathrm{a}} \mathrm{b}$ ${ }^{c}$ The different letters represent significant differences after the application of the Tukey test $(p<0.001)$. 
difference $(p<0.756)$ for this characteristic. In terms of education level, $23.55 \%$ ( \pm 5.70$)$, representing the majority of those affected, had no degree of education or did not complete elementary school. In addition, $14.95 \%( \pm 4.46)$ of the interviewees had complete elementary and incomplete secondary educations, $13.30 \%( \pm 2.37)$ had complete secondary and incomplete college educations, and $14.66 \%$ ( \pm 4.08$)$ of the individuals had completed college $(p<0.001)$.

In terms of values proportional to the population density of the regions, as displayed in Table 2, the South region, at 23.3\%, has the highest percentage of people 18 years of age or older who report chronic spine problems. The region with the second highest percentage of reports of chronic spine pain is the Northeast region, at $19.2 \%$.

Separating the data by state, as displayed in Figure 1, the six states with the highest percentages in proportion to population density are Paraná at $26 \%$, followed by Ceará at $24 \%$, Tocantins at $23.2 \%$, Rio Grande do Sul at 22\%, Maranhão at 21.5\%, and Santa Catarina at 21.3\%.

Table 2. Percentage of individuals 18 years of age and older who reported chronic spine problems in Brazil by region.

\begin{tabular}{c|c}
\hline Region & Prevalence $^{*}$ \\
\hline South & 23.33 \\
\hline Northeast & 19.18 \\
\hline Southeast & 17.02 \\
\hline Central West & 16.86 \\
\hline North & 16.85 \\
\hline
\end{tabular}

*In each 100 individuals aged 18 years or above.

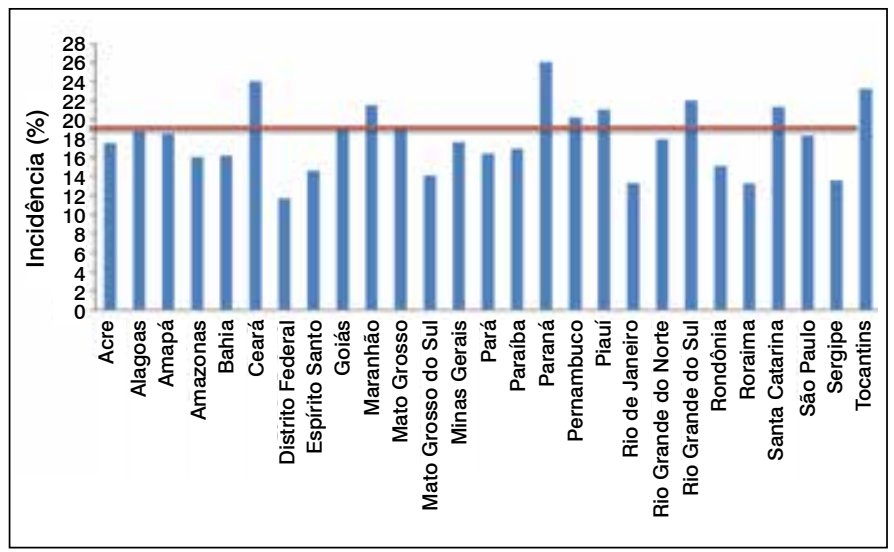

Figure 1. Incidence of spine pain by state.

\section{DISCUSSION}

The PNS data indicates that almost one fifth of the adult population (> 18 years of age), representing approximately 27 million people, reported a chronic spine problem. This condition is more frequent in women, in individuals aged 60 years or older, and among the less educated, in addition to affecting a higher proportion of individuals living in the South region of the country and a smaller proportion of residents of the states of Roraima and Rio de Janeiro.

As regards sex, women more often reported spine problems in agreement with the findings of other studies. ${ }^{7,13,16}$ This can be attributed to a series of factors, among them the fact that in general women take better care of themselves in terms of their health conditions. This characteristic reflects women's greater perception of health-related dysfunctions. Add to this the knowledge acquired in the role of the family caregiver, in addition to the fact that, as a rule, women use health services more frequently. ${ }^{16,17}$ Another important aspect that may justify the higher prevalence of spine problems in women involves pregnancy. During pregnancy, morphological changes such as increased lordosis, increased body weight, and joint instability may be contributing to the higher spine pain rate in women. There is certainly an overload on the spine resulting from postural inadequacies due to the weight of the fetus sustained by the mother and following birth of the baby, in all the care required. ${ }^{18} \mathrm{Add}$ to these factors the greater predisposition of women to the development of musculoskeletal disorders work-related or not, the hormonal aspects involved, the greater fragility of the musculoskeletal structure, double or triple shifts, and especially when they work in high-risk jobs. The high prevalence of the manifestation of fibromyalgia in women deserves mention here. ${ }^{19,20}$

When analyzing the relationship between the level of schooling and chronic spine problems, several authors were able to conclude that this condition occurs more frequently in less educated individuals. ${ }^{21,22}$ In a study of the prevalence of low back pain and the associated factors in adults conducted in São Paulo, it was observed that of the total of 84 adults with lumbalgia, $36.1 \%$ had, at a maximum, completed elementary school. ${ }^{22}$ This may be related to the work environment, given that less educated individuals end up being exposed to jobs that have greater workloads and that, consequently, generate greater physical damage. ${ }^{21,22}$

Regarding age, we observed that, in most of the studies analyzed spine pain is a condition directly proportional to the age of the individual affected, i.e., it increases with age. ${ }^{13,21}$ This may be related to the fact that in the natural human aging process people become more fragile and vulnerable to spine pathologies, causing changes in lifestyle and making them generally more dependent when performing life activities. ${ }^{23}$

In this study, the color or race variable was not associated with the prevalence of spine pain among Brazilians. In the literature, the data are controversial when these variables are associated with spine problems. Several studies have shown that most of the people with spine pain are White or Mixed race. ${ }^{13,21,24,25}$ On the other hand, we observed that White or Mixed race individuals generally predominate these studies, so it is almost impossible the determine whether any association might exist between race and spine pain.

The fact found in the research data that the greatest incidence is in the South region of Brazil can be explained in part by the increase in life expectancy and the resulting aging population. ${ }^{26-28}$ Another relevant aspect that should be considered is the propensity that the three states of the South region of Brazil have for agricultural jobs, which by the characteristics of the activities performed, have a higher frequency of spine disorders. ${ }^{29}$

Some limitations can be observed in this study, such as, for example, the generalization of the survey questionnaire that made it impossible to analyze the most affected region of the spine or to grade the intensity of the pain, although many studies describe the lumbar region as the most commonly affected by chronic problems. Another limiting aspect of this study was that the results were obtained by means of home interviews, i.e., based on the reports of the participants' perceptions, signs, and symptoms without the requirement for tests to diagnoses the disease.

Data obtained by authorities such as the IBGE, the varied information about the health of Brazilians contained in the PNS for example, should be explored by the different specialties of the health sector, enhancing the use of the data formalized in the research reports.

\section{CONCLUSION}

Based on the knowledge developed in this study, we hope that more effective public policies and actions for the functional healthcare of Brazilians can be developed that will, in fact, enable the reduction of the social damage caused by spine disorders. In this way, with the optimization of financial and human resources and through the identification of trends and grievances, actions for the promotion, prevention, and recovery of health will be able to evolve to become more effective in the day-to-day life of the population.

All authors declare no potential conflict of interest related to this article. 
CONTRIBUTION OF THE AUTHORS: LGS and WCL were the main contributors in the drafting of the manuscript. KM contributed to the statistical analysis and direction of the discussion. LGS, WCL and KM carried out the bibliographic research, the revision of the manuscript and contributed to the intellectual concept of the study, as well as final review of the work and the English version.

\section{REFERENCES}

1. Sanzarello I, Merlini L, Rosa MA, Perrone M, Frugiuele J, Borghi R, et al. Central sensitization in chronic low back pain: a narrative review. J Back Musculoskelet Rehabil. 2016;29(4):625-33.

2. Koblauch H. Low back load in airport baggage handlers. Dan Med J. 2016;63(4):pii: B5233.

3. Farber K, Wieland LS. Massage for Low-back Pain. Explore (NY). 2016;12(3):215-7.

4. Abbott $A$. Evidence base and future research directions in the management of low back pain. World J Orthop. 2016:7(3):156-61.

5. Chou R, Deyo R, Friedly J, Skelly A, Hashimoto R, Weimer M, et al. Noninvasive Treatments for Low Back Pain [Internet]. Rockville (MD): Agency for Healthcare Research and Quality (US); 2016 Feb. Disponível em: http://www.ncbi.nlm.nih.gov/books/ NBK350276/PubMed PMID: 26985522.

6. Shaikh M, Östör AJ. Evaluating the patient with low back pain. Practitioner. 2015;259(1788):21-4, 2-3

7. Schneider S, Schmitt H, Zoller S, Schiltenwolf M. Workplace stress, lifestyle and socia factors as correlates of back pain: a representative study of the German working population. Int Arch Occup Environ Health. 2005;78(4):253-69.

8. Meziat Filho N, Silva GA. Invalidez por dor nas costas entre segurados da Previdência Social do Brasil. Rev Saúde Pública. 2011;45(3):494-502.

9. Pranjić N, Maleš-Bilić L. Low back pain at new working ambient in era of new economy: a systematic review about occupational risk factors. Acta Med Croatica. 2015;69(1):49-58.

10. Laštovková A, Nakládalová M, Fenclová Z, Urban P, Gad'ourek P, Lebeda T, et al. Low-back pain disorders as occupational diseases in the czech republic and 22 european countries: comparison of national systems, related diagnoses and evaluation criteria. Cent Eur J Public Health. 2015:23(3):244-51.

11. Souza-Júnior PR, de Freitas MP, Antonaci GA, Szwarcwald CL. Desenho da amostra da Pesquisa Nacional de Saúde 2013. Epidemiol Serv Saúde. 2015;24(2):207-16.

12. Damacena GN. O processo de desenvolvimento da Pesquisa Nacional de Saúde no Brasil, 2013. Epidemiol Serv Saúde. 2015;24(2):197-206

13. Oliveira MM, Andrade SS, Souza CA, Ponte JN, Szwarcwald CL, Malta DC. Problema crônico de coluna e diagnóstico de distúrbios osteomusculares relacionados ao trabalho (DORT) autorreferidos no Brasil: Pesquisa Nacional de Saúde, 2013. Epidemiol Serv Saúde. 2015;24(2):287-96.

14. Szwarcwald CL, Mala DC, Pereira CA, Vieira ML, Conde WL, Júnior PR, et al. Pesquisa Nacional de Saúde no Brasil: concepção e metodologia de aplicação. Ciênc Saúde Coletiva. 2014;19(2):333-42.

15. Instituto Brasileiro de Geografia e Instituto Brasileiro de Geografia e Estatística (IBGE. Pesquisa Nacional de Saúde 2013: percepção do estado de saúde, estilos de vida e doenças crônicas. Rio de Janeiro: IBGE, 2014. Disponível em: <http://www.ibge.gov.br/ home/estatistica/populacao/pns/2013/>
16. Barros MB, Francisco PM, Zanchetta LM, Cesar LG. Tendências das desigualdades sociais e demográficas na prevalência de doenças crônicas no Brasil, PNAD: 2003- 2008. Ciênc Saúde Coletiva. 2011;16(9):3755-68.

17. Pinheiro RS, Viacava F, Travassos C, Brito A. Gênero, morbidade, acesso e utilização de serviços de saúde no Brasil. Ciênc Saúde Coletiva. 2002;7(4):687-707.

18. Moreira LS, Andrade SRS, Soares $V$, Avelar IS, Amaral WN, Vieira MF. Alterações posturais, de equilíbrio e dor lombar no período gestacional. FEMINA. 2011;39(5):242-4.

19. Longen WC. Ginástica laboral na prevenção de LER/DORT? Um Estudo reflexivo em uma linha de produção [dissertação]. Florianópolis, SC: Universidade Federal de Santa Catarina, Florianópolis; 2003.

20. Longen WC. Efeitos do Exercício Aeróbico e da Terapia Manual sobre Marcadores Bioquímicos de Lesão Musculoesquelética e Parâmetros Funcionais em Motoristas Profissionais com Lombalgia Crônica Inespecífica [tese]. Criciúma: Universidade do Extremo Sul Catarinense - UNESC, Programa de Pós-graduação em Ciências da Saúde; 2013

21. Almeida IC, Sá KN, Silva M, Baptista A, Matos MA, Lessa Í. Prevalência de dor lombar crônica na população da cidade de Salvador. Rev Bras Ortop. 2008;43(3):96-102.

22. Zanuto EAC, Codogno JS, Christófaro DG, Vanderlei LC, Cardoso JR, Fernandes RA Prevalência de dor lombar e fatores associados entre adultos de cidade média brasileira. Ciênc Saúde Coletiva. 2015;20(5):1575-82.

23. Hoffmann M. A prevalência de doenças lombares em pacientes de terceira idade na cidade de Concórdia/SC. Ágora: Rev Divulg Cient. 2010;17(1):62-70.

24. Furtado RLV, Ribeiro LH, Abdo BA, Descio FJ, Martucci Junior CE, Serruya DC. Dor lombar inespecífica em adultos jovens: fatores de risco associados. Rev Bras Reumatol. 2014;54(5):371-7.

25. Ferreira GD. Prevalência de dor nas costas e fatores associados em adultos do Sul do Brasil: estudo de base populacional. Rev Bras Fisioter. 2011:15(1):31-6.

26. Instituto Brasileiro de Geografia e Estatística. Síntese de indicadores sociais 2010: uma análise das condições de vida da população brasileira. Rio de Janeiro: Instituto Brasileiro de Geografia e Estatística; 2010. (Estudos e Pesquisas- Informação demográfica e Socioeconômica; 27).

27. Machado GPM, Barreto SM, Passos VMA, Lima-Costa MF. Projeto Bambuí: Prevalência de sintomas articulares crônicos em idosos. Rev Assoc Med Bras. 2004·50(4):367-72.

28. Alcantara MA, Nunes GS, Ferreira BCMS. Distúrbios Osteomusculares Relacionados ao Trabalho: o perfil dos trabalhadores em benefício previdenciário em Diamantina. Cienc Saúde Coletiva. 2011:16(8):3427-36

29. Rocha LP, Cezar-Vaz MR, Almeida MCV, Piexak DR, Bonow CA. Associação entre a carga de trabalho agrícola e as dores reacionadas. Acta Paul Enferm. 2014;27(4):333-9. 